\title{
MORPHOMETRIC AND MICROSCOPIC EVALUATION OF THE EFFECT OF GALLIUM NITRATE AS A ROOT CANAL DRESSING IN RAT TEETH SUBMITTED TO LATE REPLANTATION
}

\author{
AVALIAÇÃO MORFOMÉTRICA E MICROSCÓPICA DO EFEITO DO NITRATO DE GÁLIO \\ USADO COMO CURATIVO INTRACANAL EM DENTES DE RATOS REIMPLANTADOS \\ TARDIAMENTE
}

Graziela Garrido MORI ${ }^{1}$, Roberto Brandão GARCIA² ${ }^{2}$ Ivaldo Gomes de MORAES ${ }^{2}$, Clóvis Monteiro BRAMANTE², Norberti BERNARDINELI²

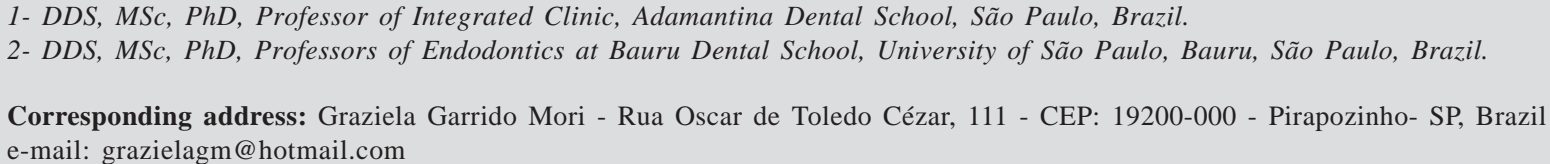

Received: November 26, 2005 - Modification: May 23, 2006 - Accepted: November 06, 2006

\begin{abstract}
T Le purpose of this study was to test a gallium nitrate solution, a resorption inhibitor, employed as a root canal dressing in teeth submitted to late replantation. Thirty maxillary right central incisors of rats were avulsed and kept dry for thirty minutes. The teeth were instrumented and the root surfaces were treated with $1 \%$ hypochlorite solution followed by application of $2 \%$ sodium fluoride. Thereafter, the teeth were divided into two groups according to the root canal dressing: Group I, solution of gallium nitrate; and Group II, calcium hydroxide paste. The teeth were then replanted in their respective sockets. The animals were killed at 15, 30 and 60 days after replantation and the samples were processed for morphometric and microscopic analysis. The results demonstrated that the gallium nitrate solution and the calcium hydroxide paste limited the root resorption, yet they did not impair its occurrence. It may be concluded that gallium nitrate solution and calcium hydroxide paste demonstrated similar performance.

Uniterms: Gallium; Root resorption; Tooth replantation; Tooth avulsion.
\end{abstract}

\section{RESUMO}

$E$

ste trabalho tem como objetivo testar a solução de nitrato de gálio, um inibidor da reabsorção, como curativo intracanal para dentes reimplantados tardiamente. Trinta incisivos centrais superiores direitos de ratos foram avulsionados e mantidos a seco por trinta minutos. Todos os dentes tiveram os canais radiculares instrumentados e a superfície radicular tratada com hipoclorito de sódio a 1\%, seguido de fluoreto de sódio a 2\%. Após isso, os dentes foram divididos em dois grupos de acordo com a medicação intracanal: no grupo I, foi usada solução de nitrato de gálio e grupo II, pasta de hidróxido de cálcio. Todos os dentes foram, então, reimplantados em seus respectivos alvéolos. Passados 15, 30 e 60 dias do reimplante, os animais foram sacrificados e as peças obtidas, processadas em laboratório para análise microscópica e morfométrica. Os resultados mostraram que a solução de nitrato de gálio e a pasta de hidróxido de cálcio limitaram a reabsorção radicular, mas não impediram a sua ocorrência. Conclui-se que ambos os medicamentos têm ação semelhante.

Unitermos: Gálio; Reabsorção radicular; Reimplante dental; Avulsão dental. 


\section{INTRODUCTION}

Accidents affecting the teeth are very common. Their consequences may range from small tooth fractures to complete displacement from the socket, characterizing tooth avulsion ${ }^{1}$.

Repair may occur after tooth replantation. However, tooth ankylosis and root resorption are often observed in most instances ${ }^{1}$. Root surface and endodontic treatments attempt to increase the occurrence of repair and reduce the presence of ankylosis and resorption ${ }^{1}$.

Sodium hypochlorite is employed for removal of necrotic tissues present on the root surface before replantation, followed by washing in saline ${ }^{10}$. The use of fluoride strengths the tooth structure by formation of fluorapatite, yet it is toxic to the resorption cells in the hard tissues ${ }^{1,14}$. The use of calcium hydroxide as a root canal dressing may avoid or limit inflammatory resorption ${ }^{17}$ due to its alkaline $\mathrm{pH}$ and bactericidal effect ${ }^{15}$, and therefore it may eliminate any infection.

Despite such treatment possibilities, there are still many cases of root resorption, and affected teeth usually must be extracted in a mean period of 4-6 years ${ }^{13}$. Hence, the search for new substances that may inhibit or delay the effects of root resorption is demanding.

Due to the similar morphology, enzymatic properties and function of cells leading to resorption of dentin, cementum and bone, the processes of root and bone resorption may be considered similar ${ }^{1,12}$. Thus, drugs or other substances that may inhibit bone resorption may also be effective for the treatment of root resorption.

Many studies have demonstrated the effectiveness of gallium nitrate in inhibiting bone resorption 2,3,4,5,19. Gallium incorporates into bone tissue, participating in the formation of fluorapatite. Thus, the newly formed bone becomes more resistant to the action of clast cells and resorption is inhibited $d^{3,45,19}$. Gallium nitrate may act on the proton pump present on the clast membrane, on the genetic expression of protein synthesis, or even on the carbonic anhydrase present on those cells ${ }^{2}$. Bockman, et al. ${ }^{4}(1995)$ verified that low doses of gallium nitrate are enough for its activity.

Assuming that gallium nitrate participates in the formation of hydroxyapatite and that the processes of bone and root resorption are similar, Ghazi, et al. ${ }^{6}$, in 2000, proposed the use of a gallium nitrate solution as a root canal dressing in teeth susceptible to root resorption. The authors reported that the gallium nitrate solution was capable of diffusing through the dentinal tubules and reach the external root surface. Studies on teeth susceptible to resorption should be conducted to confirm this. The authors have also reported that the ideal concentration of this solution is 10 ${ }^{4} \mathrm{M}$.

Based on the aspects presented, the purpose of this study was to evaluate the effect of gallium nitrate solution as a root canal dressing in avulsed replanted teeth, compared to calcium hydroxide paste.

\section{MATERIALAND METHODS}

Thirty male Wistar rats (Rattus norvegicus, albinus) weighing approximately 250-300 grams were used in this investigation. The study design was revised and approved by the Institutional Review Board on Animal Experimentation of Bauru Dental School, University of São Paulo, Brazil (process \#032/2003, October 31, 2003). The animals received pelleted food and water ad libitum.

For surgical interventions, the animals were anesthetized by intramuscular injection of a mixture of ketamine (Dopalen, Sespo Indústria e Comércio Ltda, Jacareí, SP, Brasil) and xylazine (Anasedan, Agribrands do Brasil Ltda, Jacareí, SP, Brasil) at a dose of $0.05 \mathrm{ml} / 100 \mathrm{~g}$ of weight for each drug. Asepsis of the anterior portion of the maxilla was performed with Periogard (Pfizer Ltda, São Paulo, SP, Brasil). The maxillary right central incisor was then extracted, simulating a case of tooth avulsion.

The extracted teeth were kept dry, attached to a sheet of pink wax by their crowns for 30 minutes. The dental papillae of teeth were excised with a \#11 surgical blade (Embramac Exportação e Importação, Ribeirão Preto, SP, Brasil) for exposure of root canals. The pulp was removed through the apical foramen with a slightly curved \#15 Flexofile (DentsplyMaillefer, Ballaigues, Switzerland). Root canal instrumentation was completed using \# 20 and \#25 Flexofiles. Canals were thoroughly irrigated with $1 \%$ hypochlorite solution (Probem Produtos Farmacêuticos e Odontológicos Ltda, Catanduva, SP, Brasil) using a Luer Look syringe and a 30x4 gauge needle.

After preparation, the teeth were immersed in $50 \mathrm{ml}$ of $1 \%$ hypochlorite solution for 30 minutes, washed in sterile saline and then immersed in $20 \mathrm{ml}$ of sodium fluoride solution ( $\mathrm{pH}$ 5.5) (Pharmácia Specífica, Bauru, São Paulo, Brasil) for 20 minutes. The sodium fluoride solution was prepared from a mixture of $0.1 \mathrm{M}$ phosphoric acid (pH 2) and $2 \%$ sodium fluoride (pH 8).

Root canals were further irrigated with sterile saline and filled with EDTA(Odahcam Dentsply Indústria e Comércio LTDA, Petrópolis, Rio de Janeiro, Brasil) for 3 minutes and once again washed with sterile saline. Suction was performed with a 30x4 gauge needle attached to a Luer Look syringe and the root canals were dried with sterile absorbent paper points (Tanariman Industrial Ltda, Manacapuru, Amazonas, Brasil).

The teeth were divided into two groups according to the root canal dressing used, as follows: Group I $-10^{-4} \mathrm{M}$ gallium nitrate solution (Acros Organics, Pittsburg, USA; CAS n ${ }^{\circ}$ 13494-90-1); and Group II - calcium hydroxide paste (S.S. White Artigos Dentários LTDA, Rio de Janeiro, RJ, Brasil).

Each tooth was then replanted in its respective socket. No contention was used. The animals received a single dose of 20,000 U.I. of benzathine $\mathrm{G}$ penicillin via intramuscular injection.

Five animals in each group were killed at 15, 30 and 60 days after replantation by anesthetic overdose. The right side of the maxilla was separated from the left through the median line with a \#15 surgical blade. The maxilla was further 
sectioned close to the third molar to separate the hemimaxilla containing the replanted tooth.

The specimens were fixed in $10 \%$ buffered formalin for seven days and decalcified in $4.13 \%$ EDTA ( $\mathrm{pH} 7)$. The specimens were then processed, embedded in paraffin, and transversally sectioned through the cervical, middle and apical tooth thirds; $5-\mu \mathrm{m}$ sections were obtained at each $100 \mu \mathrm{m}$ with a microtome, adding up to 20 sections for each specimen. The sections were stained with hematoxylin and eosin.

The following parameters were considered for microscopic analysis: integrity of tooth structure, presence of cementum, characteristics of the connective tissue formed in the periodontal space, presence of tooth ankylosis and occurrence of inflammatory or replacement resorption.

Morphometric analysis was also performed, with aid of the ImageLab 2000 software version 2.4 (Diracom 3, Vargem Grande so Sul, SP, Brasil), specific for measuring areas and perimeters. Fifteen histological sections of each study period were photographed with a digital camera (JVC TK-1270 Color Video Camera, Tokyo, Japão) attached to a microscope (Carl Zeiss, Axiolab, Jena, Germany) connected to a PC computer. The images were stored as figures (Tif 24) for analysis in the ImageLab software. The perimeter of areas showing ankylosis, connective tissue formed in the periodontal space, the amount of remaining cementum and the areas of inflammatory or replacement resorption were measured.

The results were organized in tables and statistically analyzed by the Kruskal-Wallis test at a significance level of $5 \%$. Whenever significant differences were found, the Dunn's test was used to assay individual comparisons.

\section{RESULTS}

Analysis of histological sections of specimens in Group I at 15 days revealed formation of a dense connective tissue, parallel (Figure 1) or perpendicular to the root surface (Figure 2 ). The presence of a periodontal ligament-like connective tissue (perpendicular direction) was decreased over time and was no longer observed at 60 days (Table 1) (Figure 3). These events were also observed in Group II (Table 1). Tooth ankylosis was observed in all study periods in both groups (Table 1).

Examination of the root surface revealed the presence of cementum covering great part of the root surface, which decreased over time in both groups (Table 2). Inflammatory resorption lacunae were observed in all study periods (Table 2) (Figure 1 and 3). In group I, replacement resorption lacunae were present at 60 days, different from the 15 and 30-day

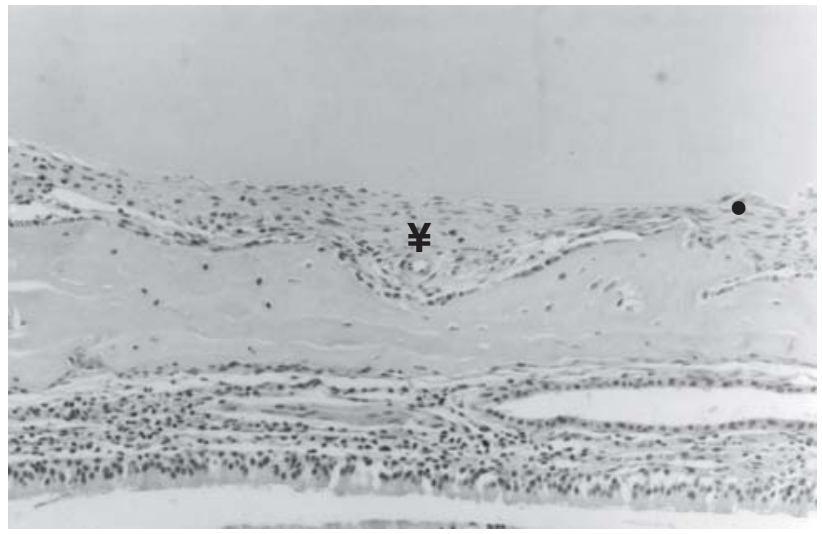

FIGURE 1- Group I, 15 days - dense connective tissue oriented in parallel direction to the root surface $(¥)$ and small resorption lacunae $(€)$

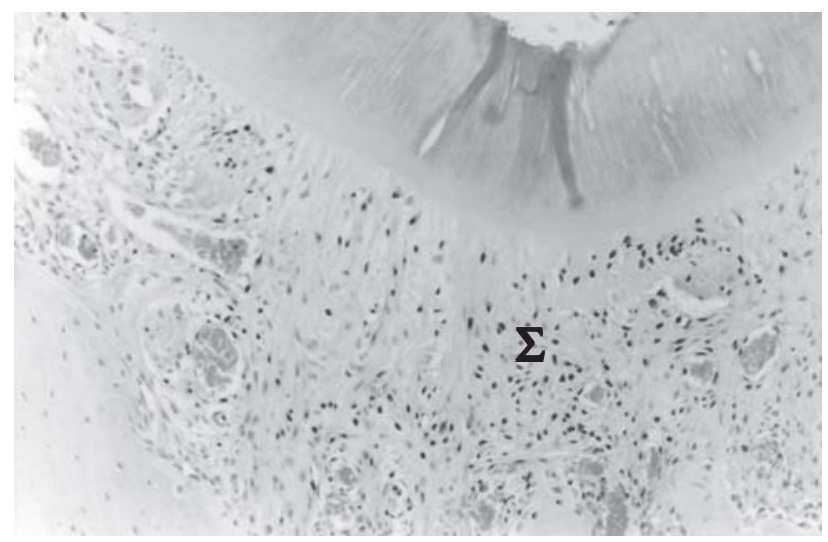

FIGURE 2- Group I, 15 days - dense connective tissue oriented in perpendicular direction to the root surface $(\Sigma)$

TABLE 1- Histological events in the periodontal space at each study period in groups I and II

\section{Histological events}

\begin{tabular}{|c|c|c|c|c|c|c|}
\hline & \multicolumn{2}{|c|}{15 days } & \multicolumn{2}{|c|}{30 days } & \multicolumn{2}{|c|}{60 days } \\
\hline & Group I & Group II & Group I & Group II & Group I & Group II \\
\hline $\begin{array}{l}\text { connective tissue parallel } \\
\text { arrangement }\end{array}$ & $42.97 \%$ & $46.74 \%$ & $79.36 \%$ & $55.82 \%$ & $66.10 \%$ & $67.38 \%$ \\
\hline $\begin{array}{l}\text { connective tissue perpendicular } \\
\text { arrangement }\end{array}$ & $30.96 \%$ & $20.59 \%$ & $8.57 \%$ & $10.17 \%$ & $0 \%$ & $0 \%$ \\
\hline ankylosis & $21.82 \%$ & $28.71 \%$ & $7.04 \% \%^{a}$ & $24.58 \%{ }^{b}$ & $18.79 \%$ & $17.29 \%$ \\
\hline
\end{tabular}

${ }^{a}$ is statistically significantly different from ${ }^{b}(p<0.05)$. 
periods, when no replacement resorption was observed (Table 2). In group II, replacement resorption was present at 30 and 60 days (Table 2).

Comparison of results obtained in groups I and II revealed that the presence of tooth ankylosis and replacement resorption lacunae was more evident in group II at 30 days $(\mathrm{p}<0.05)$. This difference was not observed at 60 days (Tables 1 and 2). In general, no statistically significant differences were observed between groups I and II, demonstrating a similar mechanism of action of both chemicals when used as root canal dressings (Tables 1 and 2).

\section{DISCUSSION}

The frequency of occurrence of root resorption in the present study groups was low, although resorption events were increasingly observed over time. This emphasizes the characteristic of gallium nitrate $\mathrm{e}^{2,3,4,5,6,19}$ and calcium hydroxide $\mathrm{e}^{7,8,16,18}$ in limiting the resorption process.

Table 2 shows the effectiveness of gallium nitrate in inhibiting replacement resorption at 15 and 30 days, since resorption was greatly increased at 60 days $(\mathrm{p}<0.05)$. This observation may indicate the need for placement of successive dressings, which might inhibit the occurrence of replacement resorption for a longer period.

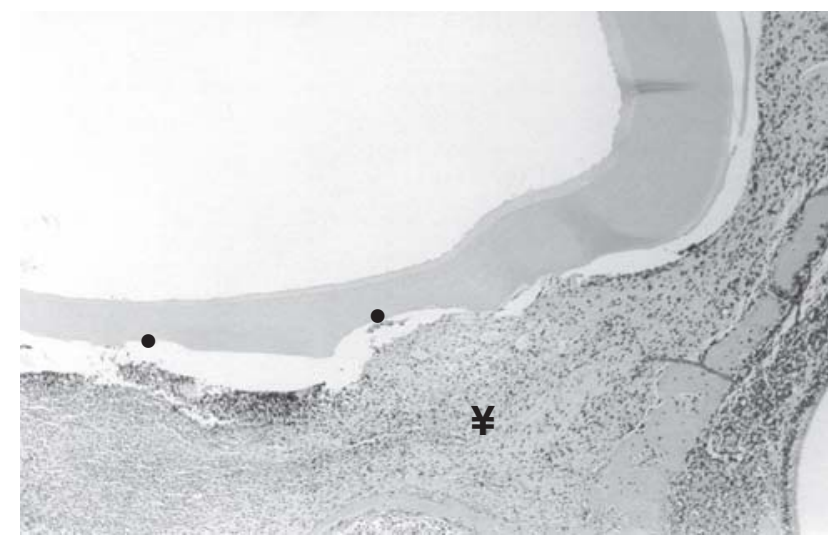

FIGURE 3 - Group I, 60 days - dense connective tissue oriented in parallel direction to the root surface ( $¥)$ and inflammatory resorption lacunae (€)
The presence of cementum could be detected on the root surface of most specimens in both groups. This suggests the efficacy of sodium hypochlorite for removal of necrotic periodontal ligament present on the root surface with no injuries to the cementum layer ${ }^{9}$. A direct proportion between the occurrence of root resorption and the absence of cementum was also noticed (Table 2).

Regarding the histological events occurring in the periodontal space, both groups exhibited tooth ankylosis. The occurrence of tooth ankylosis is related to the loss of epithelial rests of Malassez present in the periodontal ligament as a consequence of tooth avulsion, since these cells are responsible for maintaining the periodontal space ${ }^{11}$. The low frequency of tooth ankylosis affecting the present study groups is described in Table 1 . This finding may have influenced the occurrence of replacement resorption, which is a consequence of tooth ankylosis ${ }^{1,12,17}$.

The results of this study also demonstrate discrete presence of periodontal ligament-like connective tissue at 30 and 60 days (Table 1), which was considerably higher at 15 days. This may be explained by the presence of periodontal tissue remnants from the alveolar wall reaching the root surface of the replanted tooth, and not by formation of new tissue. Such periodontal tissue remnants were replaced over time by a newly formed connective tissue arranged in parallel direction to the root surface.

\section{CONCLUSION}

According to the present results, both gallium nitrate and calcium hydroxide were able to limit root resorption in teeth submitted to replantation, yet they did not prevent its occurrence. Concerning the periodontal space, formation of a periodontal ligament-like connective tissue was not favored in any group. Hence, it may be concluded that the gallium nitrate solution and calcium hydroxide paste demonstrated similar performance.

TABLE 2- Histological events on the root surface according at each study period in groups I and II

\section{Histological events}

\begin{tabular}{llllllc} 
& \multicolumn{2}{c}{15 days } & \multicolumn{2}{c}{30 days } & \multicolumn{2}{c}{$\mathbf{6 0}$ days } \\
& Group I & Group II & Group I & Group II & Group I & Group II \\
\hline presence of cementum & $95.75 \%$ & $96.05 \%$ & $93.40 \%$ & $90.58 \%$ & $83.78 \%$ & $82.78 \%$ \\
inflammatory resorption & $0.62 \%$ & $0.26 \%$ & $1 \%$ & $2.84 \%$ & $4.22 \%$ & $2.5 \%$ \\
replacement resorption & $0 \%$ & $0 \%$ & $0 \%^{\mathrm{a}}$ & $0.11 \%^{\mathrm{b}}$ & 0.58 & $0.56 \%$ \\
\hline
\end{tabular}

$a$ is statistically significantly different from ${ }^{b}(p<0.05)$. 


\section{REFERENCES}

1- Andreasen JO, Andreasen FM. Textbook and colour atlas of traumatic injuries to the teeth, 3rd ed. Copenhagen: Munksgaard Publishers; 1994.

2- Bernstein LR. Mechanisms of therapeutic activity for gallium. Pharmacol Rev. 1998;50(4):665-82.

3- Bockman RS, Boskey AL, Blumenthal NC, Alcock NW, Warrell $\mathrm{RP} \mathrm{Jr}$, et al. Gallium increases bone calcium and crystallite perfection of hydroxyapatite. Calcif Tissue Int. 1986;39(6):376-81.

4- Bockman RS, Wilhelm F, Siris E, Singer F, Chausmer A, Bitton R, et al. A multicenter trial of low dose gallium nitrate in patients with advances Paget's disease of bone. J Clin Endocrinol Metab. 1995;80(2):595-602.

5- Cournot-Witmer G, Bourdeau A, Lieberherr M, Thil CL, Plachot JJ, Enault G, et al. Bone modeling in gallium nitrate-treated rats. Calcif Tissue Int. 1987;40(5):270-5.

6- Ghazi AM, Shuttleworth S, Angulo SJ, Pashley DH. Gallium diffusion in human root dentin: qunatitative measurements by pulsed Nd:YAG laser ablation combined with na inductively coupled plasma mass spectrometer. J Clin Laser Med Surg. 2000;18(4):173-83.

7- Gregoriou AP, Jeansonne BG, Musselman RJ. Timing of calcium hydroxide therapy in the treatment of root resorption in replanted teeth in dogs. Endod Dent Traumatol. 1994;10(6):268-75.

8- Hammarström L, Blomlöf L, Feiglin B, Lindskog S. Effect of calcium hydroxide treatment on periodontal repair and root resorption. Endod Dent Traumatol. 1986;2:184-9.

9- Lindskog S, Pierce AM, Blomlof L, Hammarstrom L. The role of the necrotic periodontal membrane in cementum resorption and ankylosis. Endod Dent Traumat. 1985;1(3):96-101.

10 - Lindskog S, Pierce AM, Blomlöf L, Hammarstróm L. The role of the necrotic periodontal membrane in cementum resorption and ankylosis. Endod Dent Traumat. 1985;1(3):96-101.

11- Löe H, Waerhaug J. Experimental replantation of teeth in dogs and monkeys. Arch Oral Biol. 1961;3(3):176-84.

12- Ne RF, Witherspoon DE, Gutmann JI. Tooth resorption. Quintessence Int. 1999;30(1):9-25.

13- Pavek DI, Radtke PK. Postreplantation management of avulsed teeth: an endodontic literature review. Gen Dent. 2000;48(2):17681 .

14- Shulman LB, Gedalia I, Feingold RM. Fluoride concentration in root surfaces and alveolar bone of fluoride-immersed monkey incisors three weeks after replantation. J Dent Res. 1973;52(6):1314-6.

15- Siqueira JF Júnior, Lopes HP. Mechanisms of antimicrobial activity calcium hydroxide: a critical review. Int Endod J. 1999;32(5):361-9.

16- Tronstad L, Andreasen JO, Hasselgren G, Kristerson L, Riis I. PH changes in dental tissues after root canal filling with calcium hidroxide. J Endod. 1981;7(1):17-21.

17- Tronstad L. Root resorption-etiology, terminology and clinical manifestations. Endod Dent Traumat. 1988;4(6):241-52.

18- Vanderas AP. Effects of intracanal medicaments on inflammatory resorption or occurrence of ankylosis in mature traumatized teeth: a review. Endod Dent Traumatol.1993;9(5):175-84.
19- Warrell RP Jr. Gallium nitrate for the treatment of bone metastases. Cancer 1997;80:1680-5. 